\title{
Evaluation of noni (Morinda citrifolia) volatile profile by dynamic headspace and gas chromatography-mass spectrometry
}

\author{
Avaliação do perfil de voláteis em noni (Morinda citrifolia) por headspace dinâmico \\ e cromatografia gasosa-espectrometria de massas
}

\author{
Adriana SOUSA ${ }^{1}$, Manoel Alves SOUZA NETO ${ }^{1}$, Deborah dos Santos GARRUTI ${ }^{1}$, \\ João SOUSA ${ }^{1}$, Edy Sousa de BRITO ${ }^{1 *}$
}

\begin{abstract}
Noni is a fruit that has interested the scientific community due to its medicinal and functional activities. Different products that contain noni are already in the market, but their consumption could be impaired by their distinctive unpleasant aroma and flavor. The aim of this work was to evaluate the noni pulp volatile profile by dynamic headspace and gas chromatography-mass spectrometry. Thirty seven volatile compounds were detected, mainly alcohols (63.3\%), esters (26.9\%), cetones (7.4\%), and acids (1.2\%).

Keywords: noni; volatile compounds; GC-MS; aroma; flavor.
\end{abstract}

\section{Resumo}

O noni é um fruto que tem interessado à comunidade científica por sua atividade funcional e medicinal. Já se encontram no mercado diferentes produtos que contêm noni em sua composição, mas seu consumo tem sido prejudicado por seu aroma e sabor desagradáveis. O objetivo deste trabalho foi o de avaliar o perfil de voláteis da polpa de noni pela técnica de headspace dinâmico e cromatografia gasosa-espectrometria de massas. Foram detectados 37 compostos voláteis, sendo os principais: alcoóis $(63,3 \%)$, ésteres (26,9\%), cetonas $(7,4 \%)$ e ácidos $(1,2 \%)$.

Palavras-chave: noni; compostos voláteis; CG-EM; aroma; sabor.

\section{Introduction}

Noni comes from the Rubiaceae family which contains approximately eighty species, twenty of which have economic or other benefits. Noni stands out among its other family members because of its diverse uses, and it is able to grow in distinctly different environments including sandy areas, fertile soils, and rocky terrains. Noni is found in most South Pacific islands, Malaysia, the West Indies, Indonesia, the Philippines, Taiwan, Vietnam, India, Africa, and Guam (ELKINS, 2002).

The noni plant has traditionally been used by Polynesians for medicinal purposes for more than 2000 years (McCLATCHEY, 2002). The presence of biological compounds has been reported, such as glycosides, polysaccharides, iridoids, alkaloids, lignans, trisaccharide fatty acid esters, anthraquinones, scopoletin, morindin, vitamins, and minerals (WANG et al., 2000; LIU et al., 2001; FURUSAWA et al., 2003; SU et al., 2005). Some in vitro and in vivo analysis demonstrate that noni can confer health benefits in the form of scavenging of free radicals, antimutagenicity, anticarcinoma activity, anticlastogenic activity, inhibition of lowdensity-lipoprotein oxidation, anti-inflammatory activity, blood purification, stimulation of the immune system, regulation of cell function, and regulation of cholesterols (SALUDES et al., 2002; FURUSAWA et al., 2003; HORNICK et al., 2003; KAMIYA et al.,
2004). It is noteworthy that according to the Informe Técnico $n^{\circ} 25$ (technical safety report \#25) noni products commercialization as food should be not allowed in Brazil. This recommendation was based on the lack of scientific information regarding its safety as food (AGÊNCIA..., 2008).

Volatile compounds are responsible for the characteristic flavor of foods. These compounds are from different chemical classes present in a wide concentration range and are thermal instable. Commonly, the volatile profile is composed by dozens of compounds, but only a few have an effective contribution to the characteristic food aroma and flavor. Despite its richness in functional compounds, the consumption of noni products could be impaired by their sensory properties. The flesh of the fruit is characteristically bitter, and when completely ripe it produces a very distinctive, somewhat offensive, odor and flavor (ELKINS, 2002). Only one study was found in literature on noni fruit volatile compounds. Farine et al. (1996) analyzed a solvent extract and reported 51 volatile compounds on noni collected in Moorea (French Polynesia). These authors found 25 acids, which corresponded to $83 \%$ of the total volatile compounds, mostly low molecular weight fatty acids which are widely known as possessing strong sweat, cheese, fat, and rancid odors.

1 Tecnologia de Alimentos, Embrapa Agroindústria Tropical, CEP 60511-110, Fortaleza - CE, Brasil, E-mail: edy@cnpat.embrapa.br

${ }^{*}$ A quem a correspondência deve ser enviada 
The aim of this study was to characterize the volatile profile of noni pulp, cultivated on the Northeast of Brazil, by headspace analysis since it is generally recognized that the composition of volatile components in the vapor phase above food is more closely related to the aroma than to the composition of these compounds in the food medium itself.

\section{Materials and methods}

Noni plants were cultivated on a commercial farm in Trairí State of Ceará, Brazil. The plants were originally from Suriname and were introduced in Brazil by the Federal University of Sergipe. After harvesting, the fruits were transported to the laboratory and stored at ambient temperature for three days before pulp extraction. The pulp was collected on a pulp extractor with screen diameter of $0.2 \mathrm{~cm}$, packed in plastic bags, and stored at $-16{ }^{\circ} \mathrm{C}$ until use.

\subsection{Isolation of volatile compounds}

The volatile compounds from the headspace of the noni pulp were swept by vacuum $(70 \mathrm{mmHg})$ and concentrated into a $0.1 \mathrm{~g}$ Porapak Q trap according to the general dynamic headspace methodology described by Franco and RodriguezAmaya (1983) for soursop and adapted for other fruits by Franco, Garruti and Da Silva (1998) and Jales et al. (2006).

The Noni pulp (200 g) were diluted with $100 \mathrm{~mL}$ water, added $30 \% \mathrm{w} / \mathrm{w} \mathrm{NaCl}$, and put into the collecting apparatus (Figure 1). Suction was kept for 2 hours. Trap desorption was performed by elution with $300 \mu \mathrm{L}$ of three different solvents (acetone, hexane, and methylene chloride). All solvents employed were pure and of chromatographic grade (Em Science, Merck - Darmstadt, Germany). The Porapak Q polymer (80-100 mesh) was obtained from Waters Associates Inc (Milford, MA, USA). Prior to use in the experiment, the polymer was heated at $170{ }^{\circ} \mathrm{C}$ for 48 hours in a flow of pure nitrogen at $30 \mathrm{~mL} /$ minute.

\subsection{Gas chromatographic analysis}

Volatile compounds were separated on a CP-Sil-8CB (Varian, Walnut Creek, CA, USA), fused silica capillary column (30 m length, $0.25 \mathrm{~mm}$ id, and $0.25 \mu \mathrm{m}$ film thickness) in a

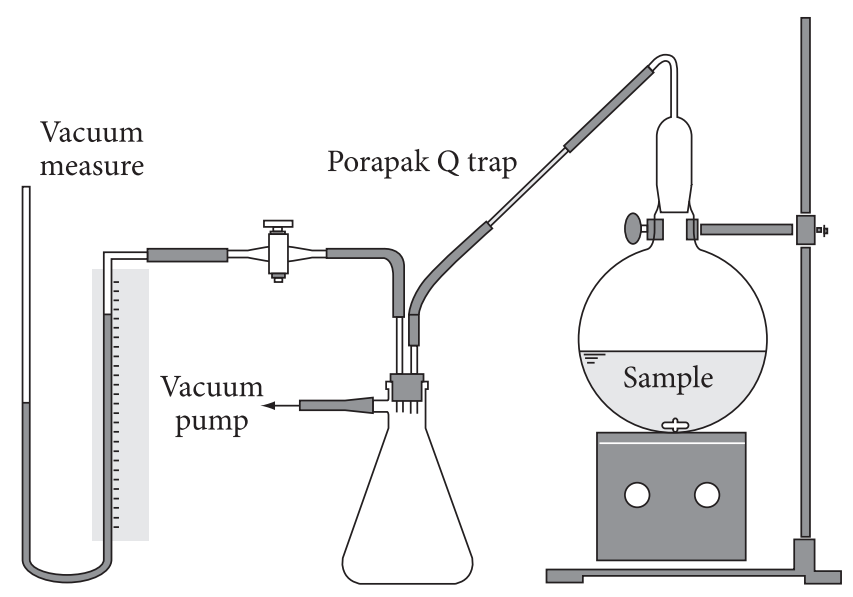

Figure 1. Entrapment system by suction.
Varian model 3800 gas chromatograph. The splitless mode injector was maintained at $220^{\circ} \mathrm{C}$ and the flame ionization detector (FID) at $250^{\circ} \mathrm{C}$. Hydrogen was the carrier gas at a flow rate of $52 \mathrm{~cm} /$ second. The oven temperature was set at $30^{\circ} \mathrm{C}$, held for 10 minutes, programmed to $90{ }^{\circ} \mathrm{C}\left(5^{\circ} \mathrm{C} /\right.$ minute $)$ and then to $200{ }^{\circ} \mathrm{C}\left(20^{\circ} \mathrm{C} /\right.$ minute $)$, held at $200{ }^{\circ} \mathrm{C}$ for 10 minutes. The injected volume was $1 \mu \mathrm{L}$.

\subsection{Gas chromatography/mass spectrometry}

The volatile compounds were identified in a Shimadzu gas chromatograph (Kyoto, Japan) coupled to a quadrupole mass spectrometer (GC/MS), model QP-2010, at $70 \mathrm{eV}$ ionization voltage and $1 \mathrm{scan} /$ second MS scan range. The column and oven conditions were the same as those used for the chromatographic analysis. Helium was the carrier gas at a flow rate of $35 \mathrm{~cm} / \mathrm{second}$.

\subsection{Retention indices}

A standard mixture of paraffin homologues C8-C21 (Polyscience $211 \mathrm{C}$ kit, Chicago, IL, USA) was prepared using methylene chloride as solvent. $1 \mu \mathrm{L}$ standard mixture was injected under the same gas chromatographic/mass spectrometry conditions for calculating linear retention indices.

\subsection{Identification of compounds}

The identification was made by matching the mass spectra of the unknown compound with those present in the computer database (National Institute for Standard Technology - NIST 02 - 147,198 compounds) and also by the comparison of their experimental retention indices with known compounds' indices (LINSTROM; MALLARD, 2008).

\section{Results and discussion}

Figure 2 shows the chromatograms of noni volatiles collected by dynamic headspace and eluted from the trap with three different solvents (acetone, hexane, and methylene chloride). The methylene chloride extract presented the richest profile with higher number of peaks and larger peaks. Therefore, it was used in further analysis for volatile identification.

Table 1 lists the 37 compounds detected in the methylene chloride extract. The peak area percentage was used to indicate the relative concentration of each compound. They were identified as seven alcohols, corresponding to $63.3 \%$ of the volatile compounds, 20 esters (26.9\%), three cetones $(7.4 \%)$, six acids (1.2\%), and one aldehyde. The major compounds, based on the relative amount, were 3-methyl-3-buten-1-ol (54.83\%), methyl hexanoate (13.04\%), methyl butanoate (8.1\%), 2-heptanone (6.86\%), and benzyl alcohol (5.2\%).

Farine et al. (1996), studying the volatile components of ripe noni fruits and their effects on drosophila, also detected significant amount of 3-methyl-3-buten-1-ol (4\%). The 3-methyl-3-buten-1-ol was reported to be the aglycone of noniosoide A (3-methylbut-3-enyl-6-O- $\alpha$-D-glucopyranosyl$\alpha$-D-glucopyranoside), a glycoside reported to be present in noni pulp (WANG et al., 2000; DALSGAARD et al, 2006). 

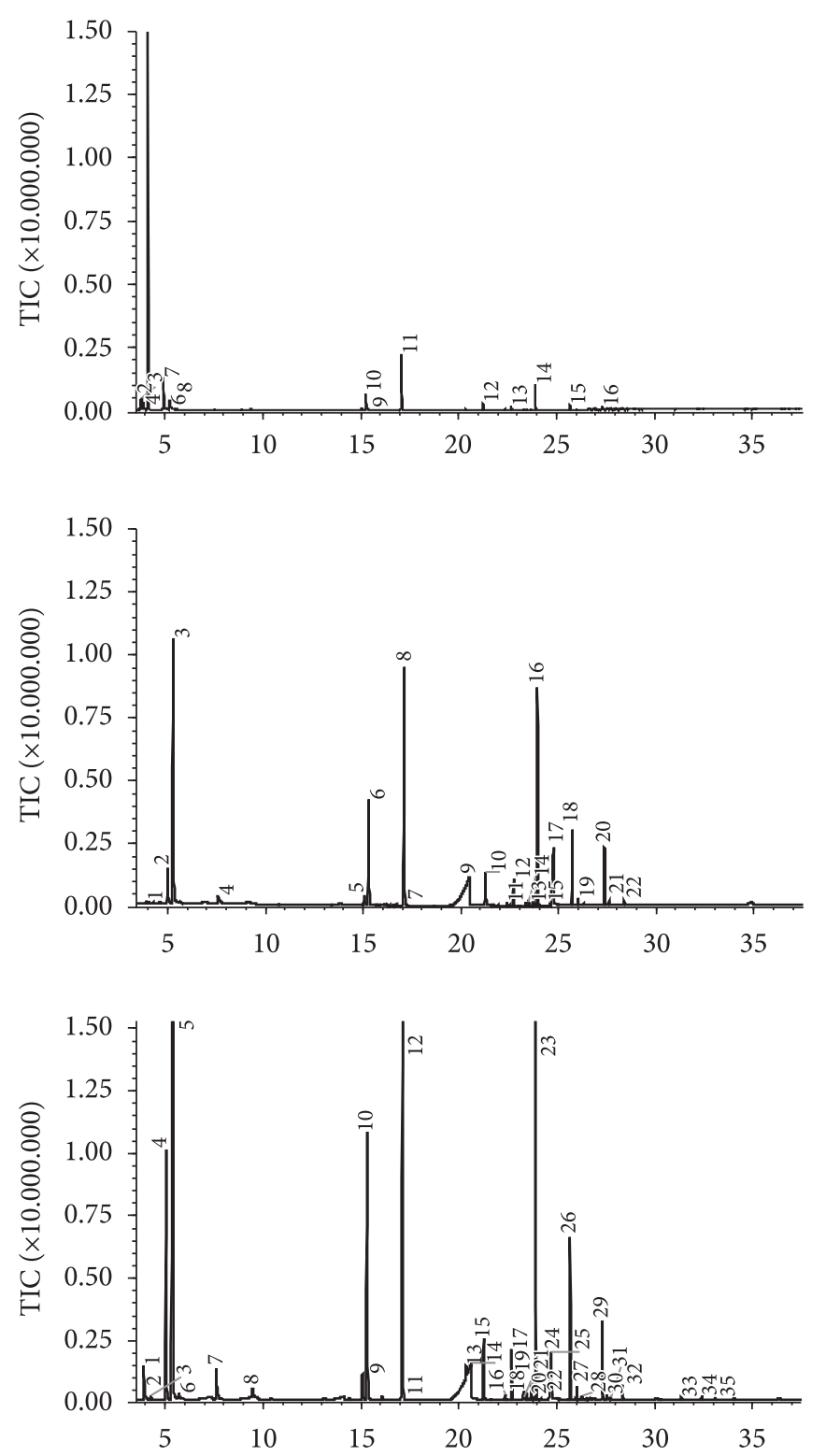

Figure 2. Effect of different desorption solvents on the profile of noni headspace volatiles.

However, Farine et al. (1996) observed a quite diverse volatile profile from that reported in the present work, with the predominance of fatty acids (83\%) and small percentage of esters (3\%). Only two compounds were found to be responsible for $77 \%$ of the total amount, octanoic acid (58\%), and hexanoic acid (19\%). The differences between these two noni profiles could be due to the volatiles isolation method employed since the cited authors used a direct solvent extraction with methylene chloride while the present work studied the headspace volatile profile. Besides, in Farine's work, the solvent extraction was carried out in a strong basic medium, which certainly liberated the fatty acids from the noni glycosides. These glycosides are esterified with fatty acids, specially hexanoic and octanoic acids, and have a trivial name of noniosides (DALSGAARD et al., 2006).
Table 1. Headspace volatile compounds from noni pulp.

\begin{tabular}{|c|c|c|c|c|}
\hline Peak no & Compound & $\begin{array}{c}\mathrm{tR} \\
\text { (minute) }\end{array}$ & IK & $\begin{array}{c}\text { Area } \\
(\%)\end{array}$ \\
\hline \multicolumn{5}{|l|}{ Ester } \\
\hline 1 & methyl 2-methylpropanoate & 3.917 & $<800$ & 1.20 \\
\hline 4 & methyl butanoate & 5.038 & $<800$ & 8.10 \\
\hline 8 & ethyl butanoate & 9.462 & 807 & 0.45 \\
\hline $8 b$ & ethyl lactate & 10.373 & 824 & 0.17 \\
\hline 9 & 4-pentenyl acetate & 15.073 & 891 & 0.53 \\
\hline 12 & methyl hexanoate & 17.132 & 931 & 13.04 \\
\hline 13 & ethyl hexanoate & 20.374 & 1000 & 0.51 \\
\hline 17 & 4-pentenyl butanoate & 22.698 & 1076 & 0.45 \\
\hline 19 & methyl benzoate & 23.350 & 1096 & 0.06 \\
\hline $20 \mathrm{~b}$ & 3-methylbutyl pentanoate & 23.623 & 1104 & - \\
\hline 21 & $\begin{array}{l}\text { 3-methyl-3-butenyl 3- } \\
\text {-methylbutanoate }\end{array}$ & 23.709 & 1114 & 0.01 \\
\hline 23 & methyl octanoate & 23.927 & 1128 & 2.19 \\
\hline 24 & ethyl benzoate & 24.651 & 1174 & 0.12 \\
\hline 27 & 3-methyl-2-butenyl hexanoate & 26.016 & 1290 & 0.04 \\
\hline 28 & methyl decanoate & 26.291 & 1322 & 0.02 \\
\hline $28 \mathrm{a}$ & ethyl 3-phenylpropanoate & 26.545 & 1354 & - \\
\hline 32 & ethyl phthalate & 28.362 & 1589 & 0.03 \\
\hline 33 & di-isobutyl phthalate & 31.353 & 1858 & - \\
\hline 34 & methyl hexadecanoate & 32.406 & 1920 & - \\
\hline 35 & dibutyl phthalate & 33.089 & 1952 & - \\
\hline \multicolumn{5}{|l|}{ Alcohols } \\
\hline 5 & 3-methyl-3-buten-1-ol & 5.397 & $<800$ & 54.83 \\
\hline 6 & $\begin{array}{l}\text { dimethyl dissulfide + 3- } \\
\text {-methyl-1-butanol }\end{array}$ & 5.713 & $<800$ & - \\
\hline 7 & 3-methyl-2-buten-1-ol & 7.595 & $<800$ & 2.69 \\
\hline $8 \mathrm{e}$ & 1-hexanol & 14.399 & 883 & 0.48 \\
\hline $15 \mathrm{a}$ & Benzyl alcohol & 21.648 & 1043 & 5.20 \\
\hline 11 & 3-methyl-2-buten-1-ol acetate & 17.042 & 929 & - \\
\hline $20 \mathrm{a}$ & nonanol & 23.587 & 1103 & 0.09 \\
\hline \multicolumn{5}{|l|}{ Acids } \\
\hline $6 a$ & 2-methylpropanoic acid & 7.379 & $<800$ & - \\
\hline $8 \mathrm{a}$ & butanoic acid & 9.729 & 812 & 0.35 \\
\hline $8 c$ & 3-methylbutanoic acid & 13.201 & 867 & 0.06 \\
\hline $8 \mathrm{~d}$ & 2-methylbutanoic acid & 14.170 & 880 & 0.09 \\
\hline 14 & hexanoic acid & 20.629 & 1009 & - \\
\hline 25 & octanoic acid & 24.729 & 1179 & 0.72 \\
\hline \multicolumn{5}{|l|}{ Ketones } \\
\hline 2 & 2-pentanone & 3.965 & $<800$ & 0.44 \\
\hline 10 & 2-heptanone & 15.310 & 894 & 6.86 \\
\hline 18 & 2-nonanone & 23.303 & 1094 & 0.08 \\
\hline \multicolumn{5}{|l|}{ Aldehyde } \\
\hline 3 & pentanal & 4.262 & $<800$ & - \\
\hline
\end{tabular}

In the present work, no modification was made in the noniosides, thus the free hexanoic and octanoic acids concentration in the noni pulp were much lower than that found by Farine. Besides, these two fatty acids show very low vapor pressure values ( 0.02 to $0.2 \mathrm{mmHg}$ ), and their concentrations in the headspace become much lower than those found in the food matrix. On the other hand, esters show vapor pressure values a hundred times higher than those of the fatty acids (above $2 \mathrm{mmHg}$ ). Such fact can explain why the predominance of this 
class of compounds was found in the headspace analysis. In addition, Farine et al. (1996) concentrated the $450 \mathrm{~mL}$ methylene chloride extracts to $500 \mu \mathrm{L}$ by Kuderna-Danish method, which, raising the temperature for a long period of time can cause large loss of esters in their extracts.

Although sensory analysis was not performed in this study, it could seem quite curious that a product with a small percentage of hexanoic and octanoic and high content of esters in its headspace can present such a sweat and cheeselike aroma. Nonetheless, it is important to point out that the impact of a volatile compound on food flavor depends on its threshold value and solubility in water or fat, besides its concentration (SHAHIDI; RUBIM; SOUZA, 1986). Hexanoic and octanoic acids present very low threshold values, 0.6 and $8 \mathrm{ppb}$, respectively (NATIONAL..., 2004), and so their odor can be perceived even in small concentrations. However, the two approaches are not exclusive, but complementary. Prior to consumption, the volatiles are sampled orthonasally, and this first sniff often has a major influence on the overall acceptability of the product. Volatiles are also released during eating, liberated from the matrix in the mastigatory process, and travel to the olfactory receptors by the retronasal route. Together with the basic tastes (sour, salty, sweet, bitter, and umami) and other oral sensations (freshness, astringency, etc) they form the food flavor. Other source of variation could be the species variability. Bicalho et al. (2000), studying cashew apple volatiles concluded that the differences found in the literature depend more on genetic variability than on the method of extraction.

\section{Conclusions}

The headspace volatiles profile of noni harvested in the Northeastern region of Brazil showed 37 compounds. The major chemical class was alcohols (63.3\%), followed by esters (26.9\%), cetones (7.4\%), and acids (1.2\%). The major compounds were 3-methyl-3-buten-1-ol, methyl hexanoate, methyl butanoate, 2-heptanone, and benzyl alcohol. Further studies are underway to identify the compounds responsible by the noni unpleasant flavor and to find a feasible process to remove them.

\section{References}

AGÊNCIA NACIONAL DE VIGILÂNCIA SANITÁRIA - ANVISA. Informe Técnico no 25: Esclarecimentos sobre as avaliações de segurança realizadas de produtos contendo Morinda Citrifolia, também conhecida como Noni. Disponível em: <http://www. anvisa.gov.br/alimentos/informes/25_290507.htm>. Acesso em: 22 dez. 2008.

BICALHO, B. et al. Application of high-temperature gas chromatography-mass spectrometry to the investigation of glycosidically bound components related to cashew apple (Anacardium occidentale L. var. nanum) volatiles. Journal of Agriculture and Food Chemistry, v. 48, p. 1167-1174, 2000.

DALSGAARD, P. W. et al. Noniosides E-H, new trisaccharides fatty acid esters from the fruit of Morinda citrifolia (Noni). Planta Medica, v. 72, p. 1322-1327, 2006.
ELKINS, R. M. H. The noni revolution: Today's tropical wonder that can battle disease, boost energy and revitalize your health. Woodland, 2002. p. 34-35.

FARINE, J. P. et al. Volatile components of ripe fruits of Morinda citrifolia and their effects on Drosophila. Phytochemistry, v. 41, p. 433-438, 1996.

FRANCO, M. R. B.; GARRUTI, D. S.; DA SILVA, M. A. A. P. Time and solvent opimization for the trapping of the volatile compounds of cashew juice and wine by suction on Porapak Q. Revista Cubana de Quimica, v. 10, p. 273-274, 1998.

FRANCO, M. R. B.; RODRIGUEZ-AMAYA, D. B. Trapping of soursop (Annonna muticata) juice volatile on Porapak Q by suction. Journal of the Science of Food and Agriculture, v. 34, p. 293-299, 1983.

FURUSAWA, E. et al. Antitumor potential of a polysaccharide-rich substance from the fruit juice of Morinda citrifolia (noni) on sarcoma180 ascites tumour in mice. Phytotherapy Research, v. 17, p. 1158-1164, 2003.

HORNICK, C. A. et al. Inhibition of angiogenic initiation and disruption of newly established human vascular networks by juice from Morinda citrifolia (noni). Angiogenesis, v. 6, p. 143-149, 2003

JALES, K. A. et al. Otimização das condições de isolamento dos voláteis do headspace do maracujá amarelo por concentração a vácuo em Porapak Q. Alimentos e Nutrição, v. 17, p. 195-201, 2006.

KAMIYA, K. et al. Chemical constituents of Morinda citrifolia fruits inhibit copper-induced low-density lipoprotein oxidation. Journal of Agricultural and Food Chemistry, v. 52, p. 5843-5848, 2004.

LINSTROM, P. J.; MALLARD, W. G. (Eds.). NIST Chemistry WebBook. NIST Standard Reference Database Number 69. Gaithersburg MD: National Institute of Standards and Technology, s.d. Disponível em: <http://webbook.nist.gov>. Acesso em: 8 set. 2008.

LIU, G. M. et al. Two novel glycosides from the fruits of Morinda citrifolia (noni) inhibit AP-1 transactivation and cell transformation in the mouse epidermal JB6 cell line. Cancer Research, v. 61, p. 5749-5756, 2001.

McCLATCHEY, W. From Polynesian healers to health food stores: Changing perspectives of Morinda citrifolia (Rubiaceae). Integrative Cancer Therapies, v. 1, p. 110-120, 2002.

NATIONAL LIBRARY OF MEDICINE. Hazardous Substances Data Bank. Bethesda, MD: 2004. Disponível em: <http://toxnet.nlm.nih. gov/2004>. Acesso em: fev. 2009.

SALUDES, J. P. et al. Antitubercular constituents from the hexane fraction of Morinda citrifolia Linn. (Rubiaceae). Phytotherapy Research, v. 16, p. 683-685, 2002.

SHAHIDI, F.; RUBIN, L. J.; D'SOUZA, L. A. Meat flavor volatiles: A review of the composition, techniques of analysis, and sensory evaluation CRC Critical Review in Food Science and Nutrition, v. 24, n. 2, p.141, 1986

SU, B. N. et al. Chemical constituents of the fruits of Morinda citrifolia (noni) and their antioxidant activity. Journal of Natural Products, v. 68, p. 592-595, 2005.

WANG, M. F. et al. Novel glycosides from noni (Morinda citrifolia). Journal of Natural Products, v. 63, p. 1182-1183, 2000. 